\title{
POROVNÁNí PŘESNOSTI MODELOVÁNí VÝNOSŮ PORTFOLIA PRO RŮZNÁ OBDOBÍ NA TRHU
}

\author{
Aleš Kresta ${ }^{1}$ \\ Klíčová slova: \\ modelování výnosů, kopula funkce, NIG model, VaR
}

\section{Key words:}

returns modelling, copula functions, NIG model, Value at Risk

\begin{abstract}
Abstrakt
Článek je zaměřen na modelování výnosů portfolia finančních aktiv, konkrétně odhad hodnoty VaR jako míry rizika tohoto portfolia. Cílem článku je zjistit, jak charakteristiky trhu ovlivní kvalitu odhadu hodnoty VaR pro mezinárodně diverzifikované portfolio akciových indexů. Při modelovaní výnosů portfolia je uvažován model založený na Studentově kopula funkci a marginálních rozděleních v podobě NIG modelu. Odhad hodnoty VaR je zpětně testován pro různá období, přičemž vývoj volatility aktiv je v těchto obdobích různý. Kvalita odhadu hodnoty VaR je posuzována na základě počtu pozorovaných výjimek a jeho srovnání s předpokládaným počtem výjimek. Z prezentovaných výsledků je patrné, že při konstantním průběhu volatility je model při odhadu hodnoty VaR přesný. Pokud však ve sledovaném období dochází ke změnám volatility, model riziko v podobě hodnoty VaR bud' podhodnocuje, nebo nadhodnocuje.
\end{abstract}

\begin{abstract}
The article is focused on the portfolio returns modelling, to be specific on the estimation of $\mathrm{VaR}$ as a portfolio risk measure. The goal of the article is to discover, how the characteristics of a market evolution influence the accuracy of $\mathrm{VaR}$ estimation of the internationally diversified portfolio of stock indices. Returns of portfolio are modelled by NIG model coupled together by Student copula function. The VaR estimation is back tested in different periods. The volatility of returns in each considered period evolves differently. The accuracy of $\mathrm{VaR}$ estimation is measured on the basis of the number of observed exceptions and its comparison to expected number of exceptions. It is apparent from the results, that for constant volatility period the model is accurate. When volatility changes in considered period, the model underestimates or overestimates the VaR.
\end{abstract}

\section{Úvod}

Při řízení finančních institucí je modelování výnosů portfolia a následný odhad rizika tohoto portfolia jednou z klíčových činností. Jako ukazatel míry rizika se nejčastěji používá hodnota Value at Risk (VaR), jejíž odhad je pro finanční instituce povinný (pro banky dle Basel II, pro pojišt'ovny dle Solvency II). Metodologie Value at Risk je v současné době nejpoužívanější mírou rizika i přes častou kritiku z důvodů nesplňování podmínek tzv. koherentní míry rizika, viz Artzner a kol. (1999). Někteří autoři proto doporučují použít jako míru rizika hodnotu conditional Value at Risk (cVaR).

\footnotetext{
${ }^{1}$ Tento př́spěvek vznikl v rámci projektu SGS VŠB-TUO 2011/7 a s využitím výpočetních zdrojů MetaCentra poskytnutých v rámci programu "Projekty velkých infrastruktur pro VaVaI" LM2010005.
} 
Hodnota VaR pro portfolio (respektive pro jednotlivá aktiva) se obvykle určuje na základě historických dat, přičemž se předpokládá nezměněný vývoj a charakteristika výnosů tohoto portfolia (respektive jednotlivých aktiv). Při modelování portfolia aktiv se obvykle využívá Sklarova teorému, pomocí kterého je sdružené rozdělení pravděpodobnosti rozloženo na dvě části: (i) jednotlivá marginální rozdělení pravděpodobnosti a (ii) funkci popisující závislost těchto jednotlivých marginálních rozdělení. Je tedy potřeba definovat dva (většinou parametrické) modely. Asi nejrozšířenějším modelem marginálních rozdělení je normální rozdělení pravděpodobnosti. Toto rozdělení pravděpodobnosti však nevystihuje empirická rozdělení výnosů finančních aktiv a proto jsou navrhovány odlišné modely, které umožňují modelovat i vyšší momenty pravděpodobnostního rozdělení. Lze uvést například zešikmené Studentovo rozdělení (Hansen, 1994), smíšené normální rozdělení a Lévyho modely, jejichž charakteristiku lze nalézt v Cont a Tankov (2003). Srovnáním vhodnosti jednotlivých modelů se zabývali Alexander a Sheedy (2008), kteří porovnávali vhodnost použití normálního rozdělení, Studentova rozdělení a smíšeného normálního rozdělení. Př́ikladem neparametrického prŕístupu je (filtrovaná) historická simulace navržená Baronem-Adesim a kol. (1999).

Zatímco př́ístupů k modelování marginálních rozdělení pravděpodobnosti je mnoho, pro modelování závislosti se nejčastěji používají eliptické kopula funkce. Aplikací kopula funkcí ve finanční oblasti se zabýval již Rank (2006). Zpětným testováním modelů s kopula funkcemi se věnoval Tichý (2010), který ověřoval přesnost odhadu hodnoty VaR pro měnové portfolio.

Cílem tohoto článku je zjistit, jak charakteristiky trhu (konkrétně vývoj volatility ve sledovaném období) ovlivní kvalitu odhadu hodnoty VaR pro mezinárodně diverzifikované portfolio akciových indexů. Při modelování výnosů tohoto portfolia bude uvažováno normální inverzní Gaussovo rozdělení sdružené Studentovou kopula funkcí, které se na základě předchozích výzkumů ukázalo jako nejvhodnější model.

Článek je členěn následovně. V první kapitole jsou charakterizovány kopula funkce, ve druhé kapitole je vysvětlen normální inverzní Gaussův model. V následujících dvou kapitolách je vysvětlena metodologie Value at Risk a postup zpětného testování včetně jednotlivých statistických testů. Ve čtvrté kapitole jsou aplikována teoretické východiska a je provedeno zpětné testování odhadu hodnoty $\mathrm{VaR}$ pro zvolená mezinárodně diverzifikovaná portfolia akciových indexů pro tři různá období. V závěru článku jsou následně shrnuty dosažené výsledky.

\section{Popis kopula funkcí}

Kopula funkce byly poprvé představeny Sklarem (Sklar, 1959). Přehled teorie spolu s praktickou aplikací pak lze nalézt v (Cherubini a kol., 2004; Nelsen, 2006). Pro jednoduchost budeme dále uvažovat dvourozměrnou kopula funkci, přičemž vše platí analogicky i pro n-rozměrné kopula funkce.

Kopula funkce je v podstatě reálná funkce, která zachycuje závislost jednotlivých distribučních funkcí v [0,1],

$$
C:[0,1]^{2} \rightarrow[0,1] \text { v } R^{2},
$$

přičemž tato funkce musí pro jakékoliv $u, v, u_{1}, u_{2}, v_{1}, v_{2} \in[0,1]$ splňovat následující podmínky: 


$$
\begin{gathered}
C(u, 0)=C(0, v)=0, \\
C(u, 1)=u, C(1, v)=v, \\
\text { pokud } u_{1} \leq u_{2}, v_{1} \leq v_{2} \text { pak } C\left(u_{2}, v_{2}\right)-C\left(u_{2}, v_{1}\right)-C\left(u_{1}, v_{2}\right)+C\left(u_{1}, v_{1}\right) \geq 0 .
\end{gathered}
$$

Na kteroukoliv kopula funkci může být pohlíženo jako na vícerozměrnou distribuční funkci s marginálními distribučními funkcemi ve formě standardizovaného rovnoměrného rozdělení. Předpokládejme dvě potencionálně závislé náhodné proměnné $X \quad$ a $Y$ s marginálními distribučními funkcemi $F_{X}$ a $F_{Y}$ a sdruženou distribuční funkcí $F_{X, Y}$. Potom dle Sklarova teorému platí:

$$
F_{X, Y}(x, y)=C\left(F_{X}(x), F_{Y}(y)\right) .
$$

Pokud jsou marginální distribuční funkce $F_{X}$ a $F_{Y}$ spojité, kopula funkce $C$ je jedinečná. Sklarův teorém naznačuje také inverzní vztah,

$$
C(u, v)=F_{X, Y}\left(F_{X}^{-1}(u), F_{Y}^{-1}(v)\right) .
$$

$\mathrm{Z}$ formulace (5) je patrné, že sdružené rozdělení pravděpodobnosti obsahuje dvě rozdílné informace: (i) marginální distribuční funkce jednotlivých náhodných proměnných, (ii) funkci závislosti těchto distribučních funkcí. Zatímco marginální distribuční funkce jsou dány pomocí $F_{X}$ a $F_{Y}$, kopula funkce $C$ popisuje pouze závislost těchto distribučních funkcí.

Za předpokladu znalosti marginálních distribučních funkcí náhodných proměnných je tedy pro potřeby modelování nezbytné zvolit vhodnou kopula funkci. S trochou zjednodušení lze rozlišit eliptické a Archimédovy kopula funkce. Hlavní rozdíl mezi těmito dvěma typy funkcí spočívá ve způsobu jejich konstrukce. Pro Archimédovy kopula funkce je potřeba definovat generující funkci (tzv. generátor). Eliptické kopula funkce vycházejí z některého známého sdruženého eliptického rozdělení pravděpodobnosti, nejpoužívanější jsou Gaussova a Studentova kopula funkce. Nevýhodou při aplikaci těchto kopula funkcí v oblasti financí je jejich symetričnost, což neodpovídá hlavně koncům sdružených rozdělení empirických dat. ${ }^{2}$ Obecně můžeme do kopula funkce dosadit dle (5) jakékoliv marginální rozdělení, ovšem použitím normálního rozdělení $\mathrm{v}$ případě Gaussovy kopula funkce získáváme sdružené normální rozdělení pravděpodobnosti a použitím Studentova rozdělení ve Studentově kopula funkci získáváme sdružené Studentovo rozdělení pravděpodobnosti.

Gaussova kopula funkce může být za předpokladu korelace mezi náhodnými proměnnými $R$ definována následovně:

$$
C_{R}^{G a}(u, v)=\Phi_{R}\left(\Phi^{-1}(u), \Phi^{-1}(v)\right),
$$

kde $\Phi^{-1}$ je inverzní funkce k distribuční funkci normovaného normálního rozdělení $\Phi, \Phi_{R}$ značí dvou-rozměrnou sdruženou distribuční funkci normovaného normálního rozdělení při korelaci $R$.

Studentova kopula funkce vychází ze Studentova rozdělení, lze ji tedy definovat následovně:

$$
C_{R, v}^{S t}(u, v)=t_{R, v}\left(t_{v}^{-1}(u), t_{v}^{-1}(v)\right)
$$

\footnotetext{
${ }^{2}$ Demarta a Mcneil (2005) např́íklad popisují zešikmenou Studentovu kopula funkci, která sice vychází ze Studentovy kopula funkce, ale není již symetrická a tudíž nepatří do třídy eliptických kopula funkcí.
} 
kde $R$ opět značí korelaci mezi náhodnými proměnnými, $t_{v}^{-1}$ je inverzní funkcí k distribuční funkci Studentova rozdělení $\mathrm{s} v$ stupni volnosti a $t_{R, v}$ je dvou-rozměrnou sdruženou distribuční funkcí Studentova rozdělení s korelací $R$ a $v$ stupni volnosti. Pomocí parametru $v$ lze u Studentovy kopula funkce ovlivnit konce rozdělení. Pro nižší hodnoty tohoto parametru je pravděpodobnost extrémního scénáře vyšší (lze tedy takto modelovat těžké konce). Naopak čím je parametr $v$ vyšší, tím více se Studentova kopule blíží Gaussově kopuli.

Existují tři hlavní př́istupy $\mathrm{k}$ odhadu parametrů při modelování pomocí kopula funkcí: EMLM (exact maximum likelihood method), IFM (inference function for margins) a CML (canonical maximum likelihood). Zatímco při použití metody EMLM jsou odhadovány všechny parametry současně, což může být výpočetně velmi náročné (obzvláště při odhadu vysoce dimenzionálních dat, nebo při použití složitějších marginálních funkcí), při IFM a CML jsou parametry marginálních rozdělení a parametry kopula funkce odhadnuty zvlášt'. V případě metody IFM jsou odhadnuty nejprve parametry marginálních distribučních funkcí a na jejich základě pak parametry kopula funkce. U metody CML jsou parametry kopula funkce odhadnuty na základě empirických distribučních funkcí. Podrobnější vysvětlení těchto metod lze nalézt např. v (Cherubini a kol., 2004). V tomto článku bude využito CML přístupu.

\section{Popis normálního inverzního Gaussova rozdělení}

V př́ipadě modelování sdruženého rozdělení pravděpodobnosti je potřeba znát dvě samostatné informace: (i) jednotlivá marginální rozdělení pravděpodobnosti a (ii) funkci popisující jejich vzájemnou závislost. Funkcím popisujícím závislost jednotlivých marginálních rozdělení byla věnována pozornost v předchozí kapitole. Pro potřeby modelování vývoje portfolia je tedy nutné ještě definovat model marginálních rozdělení pravděpodobnosti. V tomto článku je pro modelování marginálních rozdělení uvažován normální inverzní Gaussův model.

Normální inverzní Gaussův model (dále NIG) byl ve finanční literatuře představen v (Barndorff-Nielsen, 1995). Předpokládejme parametry $\alpha>0,-\alpha<\beta<\alpha$ a $\delta>0$, pak lze $N I G(\alpha, \beta, \delta)$ rozdělení pravděpodobnosti, jímž se NIG model řídí, popsat funkcí hustoty pravděpodobnosti následovně,

$$
f_{N I G}(x ; \mu, \alpha, \beta, \delta)=\frac{\alpha \delta}{\pi} \exp \left(\delta \sqrt{\alpha^{2}-\beta^{2}}+\beta(x-\mu)\right) \frac{K_{1}\left(\alpha \sqrt{\delta^{2}+(x-\mu)^{2}}\right)}{\sqrt{\delta^{2}+(x-\mu)^{2}}} .
$$

Distribuční funkce lze definovat následovně,

$$
F_{N I G}(x ; \mu, \alpha, \beta, \delta)=\frac{\alpha \delta}{\pi} \int_{-\infty}^{x} \frac{K_{1}\left(\alpha \sqrt{\delta^{2}+(t-\mu)^{2}}\right)}{\sqrt{\delta^{2}+(t-\mu)^{2}}} \exp \left(\delta \sqrt{\alpha^{2}-\beta^{2}}+\beta(t-\mu)\right) d t,
$$

kde $K_{j}(x)$ značí modifikovanou Besselovu funkci druhého druhu. Populační momenty tohoto rozdělení jsou shrnuty v tabulce č. 1 . 
Tab. 1: Populační momenty NIG rozdělení

\begin{tabular}{|l|l|}
\hline Populační moment & Vzorec \\
\hline Střední hodnota & $\mu+\delta \beta\left(\alpha^{2}-\beta^{2}\right)^{-\frac{1}{2}}$ \\
\hline Rozptyl & $\alpha^{2} \delta\left(\alpha^{2}-\beta^{2}\right)^{-\frac{3}{2}}$ \\
\hline Šikmost & $3 \beta \alpha^{-1} \delta^{-\frac{1}{2}}\left(\alpha^{2}-\beta^{2}\right)^{-\frac{1}{4}}$ \\
\hline Špičatost & $3\left(1+\frac{\alpha^{2}+4 \beta^{2}}{\delta \alpha^{2} \sqrt{\alpha^{2}-\beta^{2}}}\right)+3$ \\
\hline
\end{tabular}

Parametry $\mu, \alpha, \beta$ a $\delta$ tohoto pravděpodobnostního rozdělení mohou být odhadnuty dvěmi metodami: (i) metodou maximální věrohodnosti a (ii) metodou momentů. Použití metody maximální věrohodnosti je při odhadu parametrů NIG rozdělení časově/početně velmi náročné, vhodnější se proto jeví použití metody momentů. Položíme-li populační momenty uvedené v tabulce č. 1 rovny momentům výběru, získáme následující odhady parametrů NIG rozdělení:

$$
\begin{gathered}
\hat{\mu}=m-\frac{3 s \sqrt{v}}{3 k-4 s^{2}-9}, \\
\hat{\alpha}=\sqrt{\frac{3 k-4 s^{2}-9}{v\left(k-\frac{5}{3} s^{2}-3\right)^{2}},} \\
\hat{\beta}=\frac{s\left(k-\frac{5}{3} s^{2}-3\right)}{\sqrt{v}}, \\
\hat{\delta}=3^{\frac{3}{2}} \frac{\sqrt{v\left(k-\frac{5}{3} s^{2}-3\right)}}{3 k-4 s^{2}-9},
\end{gathered}
$$

kde $m$ je střední hodnota výběru, $v$ je rozptyl výběru, $s$ je výběrový koeficient šikmosti, $k$ je výběrový koeficient špičatosti. Detailnější informace lze nalézt v (Prause, 1999).

\section{Charakteristika metodologie Value at Risk a conditional Value at Risk}

Value at Risk (dále VaR) je metodou hodnocení rizika, která se dnes používá hlavně v oblasti finančních institucí. VaR v podstatě vyjadřuje maximální možnou ztrátu na určité hladině spolehlivosti $\alpha$. Formálně lze VaR definovat následovně:

$$
\operatorname{Pr}\left(\Delta \Pi_{t+\Delta t} \leq-V a R_{\alpha, \Delta t}\right)=1-\alpha,
$$

kde $\Delta \Pi$ vyjadřuje náhodnou veličinu - zde konkrétně změnu ceny portfolia za čas $\Delta t$, $V a R_{\alpha, \Delta t}$ je maximální ztráta na dané hladině spolehlivosti $\alpha$ pro časový horizont $\Delta t$ a $\operatorname{Pr}$ značí pravděpodobnost. Hodnota $1-\alpha$ se nazývá hladina významnosti. $\mathrm{Na} \mathrm{VaR}$ lze v podstatě pohlížet jako na $\alpha$ kvantil (hladina spolehlivosti) pravděpodobnostního rozdělení ztrát nebo jako na záporný $1-\alpha$ kvantil (hladina významnosti) pravděpodobnostního rozdělení výnosů. 
Nejčastěji používané hladiny významnosti, $15 \%, 1 \%$ a $0,5 \%$, jsou zároveň zakotveny v legislativou stanovených metodologiích. Rovněž časový horizont, pro který je hodnota VaR počítána, může být pro jednotlivé instituce různý - pro banky dle metodologie Basel II je to 10 dní, pro pojišt'ovny dle metodologie Solvency II pak jeden rok. Obecně je však hodnota VaR počítána spíše pro kratší časové intervaly, nejčastěji pro jeden den, a následně je přepočtena pro delší časové období.

Mnoho autorů metodologii Value at Risk kritizuje. Hlavním důvodem kritiky je, že VaR obvykle nesplňuje vlastnosti koherentní míry rizika (Artzner a kol., 1999), konkrétně podmínku subaditivity ${ }^{3}$. Hodnota VaR také neříká nic o rozdělení extrémních ztrát, které jsou vetší než tato hodnota. $Z$ těchto důvodů se čím dál více prosazuje metodologie conditional Value at Risk (dále cVaR, nebo také „expected shortfall“ či „tail Value at Risk“). Conditional Value at Risk lze definovat jako střední hodnotu ztráty převyšující hodnotu VaR na dané hladině spolehlivosti:

$$
c V a R_{\alpha}=\mathrm{E}\left(-\Delta \Pi_{t+\Delta t} \mid \Delta \Pi_{t+\Delta t}<-V a R_{\alpha, \Delta t}\right),
$$

kde $\Delta \Pi$ opět vyjadřuje změnu ceny portfolia.

\section{Popis postupu zpětného testování (backtestingu)}

Kvalitu odhadu hodnoty $\mathrm{VaR}$ je potřeba (nejen z důvodu legislativních nařízení) ověřit na minulých datech. Předpokládejme, že máme model, který odhaduje hodnotu VaR na určité hladině spolehlivosti $\alpha$. Pro jednoduchost dále předpokládejme, že odhadujeme hodnotu VaR pro interval jednoho dne. Při backtestingu postupujeme tak, že pro jednotlivé dny porovnáváme hodnotu $\mathrm{VaR}$ určenou modelem na základě informací známých předchozí den k uvažovanému dni a pozorovanou ztrátou uvažovaného dne. Dny, ve kterých skutečná ztráta přesáhne hodnotu VaR, se nazývají výjimky. Pokud zaznamenáme výjimky v přibližně $1-\alpha$ procentech případů, odhaduje model hodnotu $\mathrm{VaR}$ správně. $\mathrm{V}$ případě vyššího výskytu výjimek model riziko podhodnocuje, v př́ípadě nižšího počtu výjimek model riziko nadhodnocuje. Blíže se tímto postupem zabývá Hull (2007).

Postup ověření modelu pomocí zpětného testování v př́ípadě odhadu tržního rizika je tedy následující: (i) uvažujeme výpočet hodnoty VaR pro den $x$, (ii) pro odhad modelu použijeme časové řady korespondující s intervalem $x-m$ až $x-1$, kde $m$ je zvolená délka časové řady, na jejímž základě budeme model odhadovat, (iii) odhadnutým modelem určíme hodnotu VaR pro jeden den a tuto hodnotu porovnáme se skutečnou ztrátou zaznamenanou dne $x$, (iv) dále postup opakujeme pro další dny, tzn. proměnnou $x$ zvýšíme vždy o jedničku (jeden den), celkem předpokládáme $n$ pozorování. Schematicky je postup volby časové řady pro odhad modelu a časové řady pro ověření znázorněn na obrázku č. 1.

\footnotetext{
${ }^{3}$ Podmínka subaditivity vyjadřuje, že pro dvě náhodné veličiny $Z_{1}$ a $Z_{2}$ musí funkce rizikové míry $\rho$ splňovat podmínku $\rho\left(Z_{1}+Z_{2}\right) \leq \rho\left(Z_{1}\right)+\rho\left(Z_{2}\right)$. Toto je pro VaR splněno pouze pro některá eliptická rozdělení pravděpodobnosti.
} 
Obr. 1: Posouvání intervalu (moving window) vstupních dat pro výpočet hodnoty VaR pro jednotlivé dny

\begin{tabular}{|c|c|c|c|c|c|c|c|c|}
\hline den $x-m$ & $\ldots$ & den $x-2$ & den $x-1$ & $\operatorname{den} x$ & & & & interval pro odhad \\
\hline & den $x-m$ & $\ldots$ & den $x-2$ & den $x-1$ & $\operatorname{den} x$ & & & interval pro ověření \\
\hline & & den $x-m$ & $\ldots$ & den $x-2$ & den $x-1$ & $\operatorname{den} x$ & & \\
\hline & & & den $x-m$ & $\ldots$ & den $x-2$ & den $x-1$ & $\operatorname{den} x$ & \\
\hline & & & & den $x-m$ & $\ldots$ & den $x-2$ & den $x-1$ & $\operatorname{den} x$ \\
\hline & & & & & den $x-m$ & $\ldots$ & den $x-2$ & den $x-1$ \\
\hline
\end{tabular}

V podstatě tímto postupem ověřujeme, že pravděpodobnost výskytu výjimky je rovna hodnotě $1-\alpha$, tedy hladině významnosti. Tuto rovnost je potřeba statisticky otestovat. Pro potřeby statistických testů je nutné definovat proměnnou $I_{t}$, která nabývá hodnoty jedna, pokud v den $t$ skutečná ztráta překročí pro tento den odhadnutou hodnotu $V_{a} R_{\alpha, t}$ (jedná se o výjimku), a hodnoty nula, pokud skutečná ztráta $\mathrm{v}$ den $t$ hodnotu $V a R_{\alpha, t}$ nepřekročí. Ke statistickému testování počtu výjimek lze využít bud' binomické rozdělení nebo vhodnější test navržený Kupiecem (Kupiec, 1995), který je oboustranný a tudíž testuje nevhodnost modelu jak z pohledu podhodnocení tak nadhodnocení rizika. Tento test je založen na následujícím věrohodnostním poměru (likelihood ratio):

$$
L R=\frac{\pi_{o c k}^{n_{1}}\left(1-\pi_{o c k}\right)^{n_{0}}}{\pi_{p o z}^{n_{1}}\left(1-\pi_{p o z}\right)^{n_{0}}}
$$

kde $n_{i}$ je počet pozorování, pro které platí $I_{t}=i, \pi_{o c k}$ je očekávaná pravděpodobnost nastání výjimky (tedy $\pi_{o c k}=1-\alpha$ ) a $\pi_{p o z}$ je pozorovaná pravděpodobnost nastání výjimky, $\pi_{p o z}=\frac{n_{1}}{n_{0}+n_{1}}$. Přičemž $-2 \ln (L R)$ má asymptoticky chí kvadrát rozdělení s jedním stupněm volnosti. Testovací statistiku lze tedy přepsat do tvaru:

$$
-2 \ln (L R)=2 \ln \left[\left(1-\frac{n_{1}}{n_{0}+n_{1}}\right)^{n_{0}}\left(\frac{n_{1}}{n_{0}+n_{1}}\right)^{n_{1}}\right]-2 \ln \left[\alpha^{n_{0}}(1-\alpha)^{n_{1}}\right],
$$

kde proměnné mají stejný význam jako v předchozí rovnici.

\section{Zpětné testování odhadu tržního rizika}

V této kapitole bude zpětně testován odhad rizika v podobě hodnoty VaR pro zvolené mezinárodně diverzifikované portfolio akciových indexů. Bude tak navázáno na výzkum provedený v (Tichý, 2010), portfolio citlivé pouze na měnové riziko bude rozšsiřeno o riziko akciové.

Předpokládány budou investice do zahraničních akciových indexů z pohledu českého investora - rizikovým faktorem bude tedy výnos indexu a výnos příslušného měnového kurzu. Dále budou uvažovány tři portfolia složená z akciových indexů při zohlednění příslušných měnových kurzů. Výnos portfolia bude modelován pomocí eliptických kopula funkcí, jako marginální rozdělení bude uvažován NIG model. 


\subsection{Popis vstupních dat a použitého modelu}

Zpětné testování odhadu tržního rizika bude prováděno na různých portfoliích čtyř akciových indexů, konkrétně americkém Down Jones Industrial Average (DJI), britském FTSE 100 (FTSE), japonském Nikkei 225 (N225) a švýcarském Swiss Market Index (SMI). Vzhledem $\mathrm{k}$ tomu, že indexy jsou denominovány $\mathrm{v}$ jiných měnách než českých korunách, budou $\mathrm{v}$ portfoliu zastoupeny i měnové kurzy, konkrétně se jedná o americký dolar (USD), britskou libru (GBP), japonský jen (JPY) a švýcarský frank (CHF). U všech těchto měn je uvažován měnový kurz vůči české koruně $(\mathrm{CZK})$. Časové řady těchto aktiv byly získány ze serveru české národní banky (kurzy jednotlivých měn vůči české koruně) a serveru finance.yahoo.com (kurzy jednotlivých indexů) za období od 25. 9. 1997 do 31. 12. 2009. Jednotlivé časové řady byly spojeny do matice tak, aby se v každém řádku vyskytovaly příslušné kurzy k patř̌ičnému dni. Chybějící údaje byly interpolovány ze dvou nejbližších nechybějících sousedních hodnot a následně byl proveden převod na matici spojitých denních výnosů. Takto byly získány časové řady o délce 3189 pozorování. Charakteristiky jednotlivých časových řad výnosů za zvolené období jsou shrnuty v tabulce č. 2.

Tab. 2: Základní charakteristiky spojitých výnosů vstupních časových řad vybraných aktiv

\begin{tabular}{|l|r|r|r|r|r|r|r|}
\hline Aktivum & $\begin{array}{c}\text { Minimální } \\
\text { výnos }\end{array}$ & $\begin{array}{c}\text { Maximální } \\
\text { výnos }\end{array}$ & $\begin{array}{c}\text { Střední } \\
\text { hodnota }\end{array}$ & Medián & $\begin{array}{c}\text { Směrodatná } \\
\text { odchylka }\end{array}$ & Šikmost & Špičatost \\
\hline DJI & $-8,201 \%$ & $10,508 \%$ & $0,009 \%$ & $0,040 \%$ & $1,260 \%$ & $-0,025$ & 10,505 \\
\hline FTSE & $-9,265 \%$ & $9,384 \%$ & $0,002 \%$ & $0,046 \%$ & $1,299 \%$ & $-0,106$ & 8,671 \\
\hline N225 & $-12,111 \%$ & $10,086 \%$ & $-0,017 \%$ & $0,023 \%$ & $1,558 \%$ & $-0,408$ & 8,205 \\
\hline SMI & $-8,108 \%$ & $10,788 \%$ & $0,005 \%$ & $0,056 \%$ & $1,309 \%$ & $-0,020$ & 8,395 \\
\hline USD & $-4,818 \%$ & $4,333 \%$ & $-0,019 \%$ & $-0,036 \%$ & $0,772 \%$ & 0,121 & 5,764 \\
\hline GBP & $-4,871 \%$ & $3,995 \%$ & $-0,019 \%$ & $-0,021 \%$ & $0,643 \%$ & $-0,037$ & 7,602 \\
\hline JPY & $-5,253 \%$ & $5,448 \%$ & $-0,010 \%$ & $-0,041 \%$ & $0,920 \%$ & 0,272 & 6,111 \\
\hline CHF & $-3,063 \%$ & $2,927 \%$ & $-0,008 \%$ & $-0,018 \%$ & $0,539 \%$ & 0,297 & 7,525 \\
\hline
\end{tabular}

Z tabulky č. 2 je zřejmých několik poznatků. Indexy jsou více volatilní než měnové kurzy. Toto je jednak dáno vyšší hodnotou směrodatné odchylky, ale také i vyšším rozpětím maximálního a minimálního výnosu. U všech časových řad lze pozorovat nenulovou šikmost a značnou špičatost. Indexy jsou zešikmeny doleva - pro ztráty jsou tedy pravděpodobnější vyšší hodnoty, kdežto zisky jsou spíše menší, ale více pravděpodobné. Měnové kurzy, až na výjimku JPY, jsou naopak zešikmeny doprava - časová řada obsahuje relativně hodně malých ztrát a v případě výnosů jsou tyto vysoké. Již z pohledu na hodnoty koeficientu šikmosti a špičatosti je zřejmé, že normální rozdělení není vhodné pro modelování těchto časových řad. Toto potvrzuje i Jarque-Bera test, pomocí kterého můžeme pro všechny časové řady na 5\% hladině pravděpodobnosti zamítnout nulovou hypotézu, že řada má normální rozdělení.

Budou předpokládány jednak investice do jednotlivých indexů (včetně zahrnutí měnového rizika) a také tři různá portfolia složená ze dvou a více akciových indexů. Při modelování investice do jednotlivých indexů se bude jednat o portfolio složené z jednoho aktiva (akciový index) závislé na dvou rizikových faktorech (výnos akciového indexu v zahraniční měně a výnos měnového kurzu). Výnos tohoto portfolia bude tedy určen jako součet výnosu akciového indexu a měnového kurzu. ${ }^{4} \mathrm{U}$ portfolií složených $\mathrm{z}$ více akciových indexů budou uvažována tato portfolia: (i) tangenciální portfolio $\Pi_{\mathrm{m}}$, váhy tohoto portfolia byly určeny dle

\footnotetext{
${ }^{4}$ Jedná se o spojitý výnos.
} 
Zmeškal (2004, s. 90-91) s uvažovanou zápůjční i výpůjční úrokovou sazbou rovnou nule, (ii) rovnoměrně citlivé portfolio $\Pi_{\mathrm{eq}}$, kdy každý index (potažmo i měnový kurz) má v portfoliu stejnou váhu, (iii) portfolio s minimálním rozptylem $\Pi_{\mathrm{mv}}$, váhy tohoto portfolia byly určeny dle Zmeškal (2004, s. 79). Váhy aktiv v jednotlivých portfoliích jsou shrnuty v tabulce č. 3 .

Tab. 3: Složení uvažovaných portfolií

\begin{tabular}{|l|r|r|r|r|}
\hline \multicolumn{1}{|c|}{ Portfolio - označení } & DJI, USD & FTSE, GBP & N225, JPY & SMI, CHF \\
\hline DJI, USD & $100 \%$ & $0 \%$ & $0 \%$ & $0 \%$ \\
\hline FTSE, GBP & $0 \%$ & $100 \%$ & $0 \%$ & $0 \%$ \\
\hline N225, JPY & $0 \%$ & $0 \%$ & $100 \%$ & $0 \%$ \\
\hline SMI, CHF & $0 \%$ & $0 \%$ & $0 \%$ & $100 \%$ \\
\hline Tangenciální portfolio & $29,79 \%$ & $0,00 \%$ & $0,00 \%$ & $70,21 \%$ \\
\hline Rovnoměrně složené portfolio & $25,00 \%$ & $25,00 \%$ & $25,00 \%$ & $25,00 \%$ \\
\hline Portfolio s minimálním rozptylem & $34,25 \%$ & $11,15 \%$ & $21,62 \%$ & $32,98 \%$ \\
\hline
\end{tabular}

K modelování výnosů portfolia (vícerozměrné sdružené rozdělení pravděpodobnosti) bude použito kopula přístupu, konkrétně bude použita Studentova kopula funkce (8) s marginálními rozděleními v podobě NIG modelu (10). Odhad parametrů bude proveden ve dvou krocích pomocí CML prŕístupu, který byl zvolen s ohledem na časovou úsporu v porovnání s přístupy IFM a EMLM. Byly tedy odhadnuty zvlášt' parametry marginálních rozdělení a zvlášt' parametry kopula funkcí, při odhadu parametrů obou se vycházelo z posledních 250 dní. Odhad hodnoty VaR byl proveden metodou simulace Monte Carlo s 50 tisíci scénáři pro pozorování číslo 251 (14. září 1998) až 3189 (29. prosinec 2009), a následně pro jednotlivé třetiny tohoto období, viz tabulka č. 4.

Tab. 4: Délka jednotlivých uvažovaných období

\begin{tabular}{|l|l|l|c|}
\hline Období & Začátek období & Konec období & $\begin{array}{l}\text { Počet } \\
\text { pozorování }\end{array}$ \\
\hline Celé období & $251(14$. záŕí 1998) & $3189(29$. prosinec 2009) & 2939 \\
\hline První třetina & $251(14$. zář́ 1998) & $1230(20$. května 2002) & 980 \\
\hline Druhá třetina & $1230(20$. května 2002) & $2209(24$. března 2006) & 980 \\
\hline Třretí třetina & $2210(27$. března 2006) & $3189(29$. prosinec 2009) & 980 \\
\hline
\end{tabular}

Výnosy jednotlivých finančních aktiv jsou zachyceny na obrázku č. 2. Lze vidět, že vývoj volatility výnosů je v jednotlivých třetinách uvažovaného období různý. Pro první třetinu platí, že volatilita je pro všechna aktiva konstantní. Na začátku druhé třetiny lze pro akciové indexy pozorovat zvýšenou volatilitu, která postupně během tohoto období klesá. Volatilita měnových kurzů je ve druhém období konstantní. Ve třetím období dochází ke skokovému nárůstu volatility (druhá polovina roku 2008) a jejímu následnému snížení. Nárůst volatility ve třetím období je způsoben finanční krizí, která měla na vývoj akciových indexů a měnových kurzů silný vliv.

Lze tedy předpokládat, že model bude dosahovat nejlepších výsledků v první třetině uvažovaného období (vzhledem ke konstantní volatilitě). Naopak výnosy a tedy i hodnota VaR bude modelem těžko predikovatelná ve třetí třetině uvažovaného období (vzhledem k vysokým změnám volatility).

\subsection{Výsledky zpětného testování}

Výsledky zpětného testování modelu pro celé uvažované období a pro jednotlivé třetiny tohoto období (viz tabulka č. 4) jsou shrnuty v tabulce č. 5. Vzhledem k 3189 testovacím 
pozorováním v celém období lze předpokládat pro hladiny významnosti $85 \%, 95 \%, 99 \%$ a $99,5 \%$ tyto počty výjimek: $441,147,29,15$. Pro třetiny tohoto období je vzhledem k 980 pozorováním předpokládáno postupně $147,49,10$ a 5 výjimek.

Obr. 2: Pozorované výnosy jednotlivých uvažovaných finančních aktiv (postupně shora doprava DJI, FTSE, N225, SMI, USD, GBP, JPY, CHF), jednotlivé třetiny uvažovaného období jsou odděleny svislou čárou.
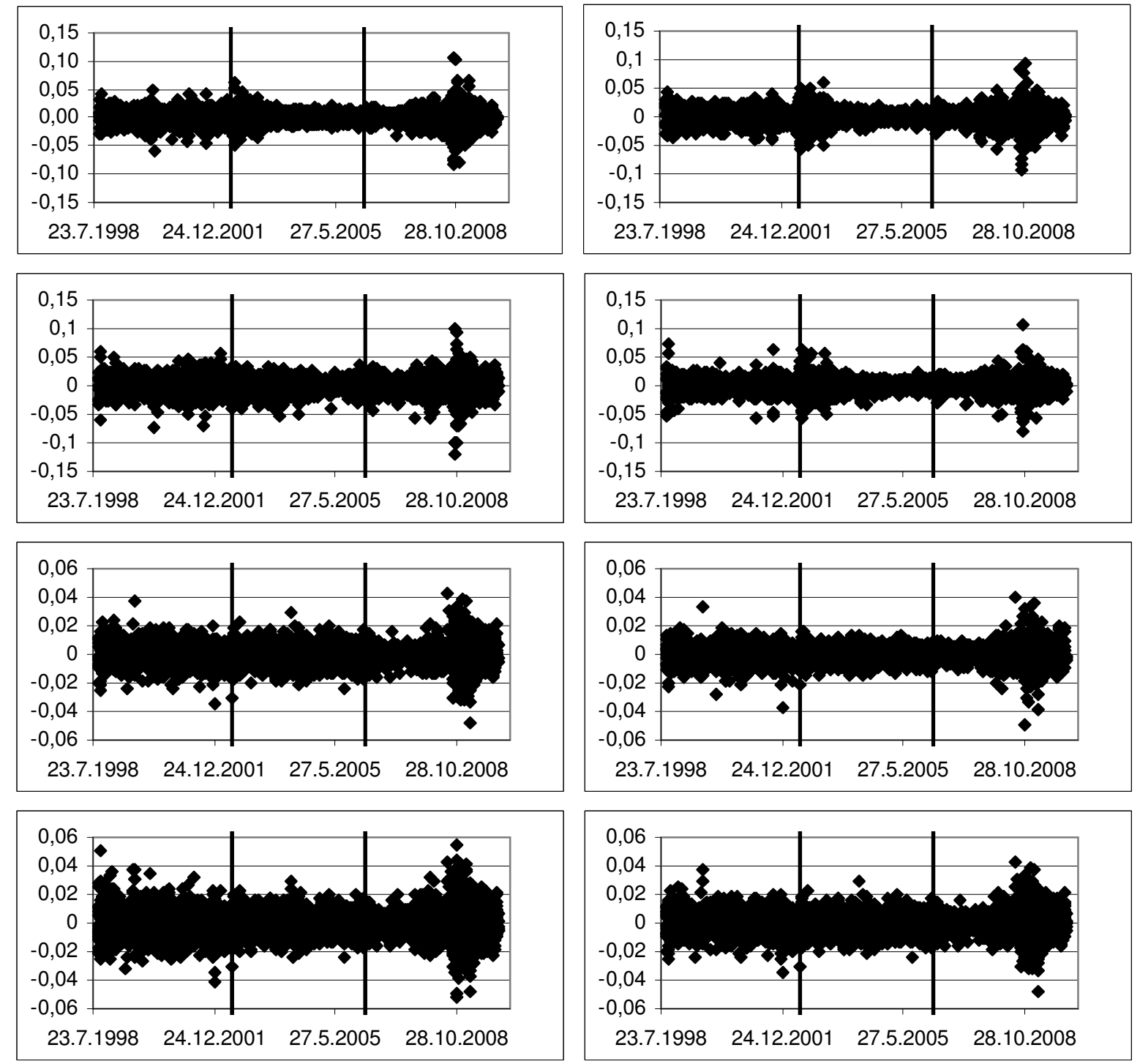

Budeme-li model posuzovat na základě celého období, lze jej považovat za velmi přesný. Kromě investice do DJI, USD a odhadu hodnoty VaR na hladině spolehlivosti $99,5 \%$ lze pro všechna ostatní portfolia a hladiny spolehlivosti model považovat dle Kupiecova testu na 5\% hladině významnosti za spolehlivý a přesný.

Zaměříme-li se pouze na první třetinu uvažovaného období, jsou skutečné počty výjimek velmi blízké očekávanému počtu. Lze pozorovat, že podmínky Kupiecova testu jsou splněny pro všechna portfolia a hladiny spolehlivosti. První třetina uvažovaného období je charakteristická relativně konstantní volatilitou. Lze tedy usuzovat, že v př́ípadě, že nedochází ke změnám volatility, je tento model velmi přesný. 
Naproti tomu ve druhé a třetí třetině uvažovaného období již model obdobných výsledků nedosahuje. Ve druhé třetině sledovaného období je pro většinu portfolií a hladin spolehlivosti skutečný počet výjimek statisticky nižší než počet předpokládaný. Toto lze vysvětlit postupně se snižující volatilitou výnosů ve druhé třetině uvažovaného období. Vzhledem k tomu, že je model kalibrován vždy na minulých datech, je odhadnutá volatilita vyšší, a tudíž nedochází k tolika výjimkám. Uvažovaný model tudíž riziko nadhodnocuje.

Tab. 5: Skutečné a předpokládané počty výjimek pro jednotlivá uvažovaná portfolia a hladiny spolehlivosti. Tučně jsou zvýrazněny skutečné počty výjimek, které lze na základě Kupiecova testu na 5\% hladině významnosti pokládat za dostatečně přesné.

\begin{tabular}{|c|c|c|c|c|c|c|}
\hline Portfolio & $\begin{array}{r}\text { Hladina } \\
\text { spol. } \\
\text { hodnoty } \\
\mathrm{VaR}, \alpha \\
\end{array}$ & $\begin{array}{r}\text { Předpoklá- } \\
\text { daný počet } \\
\text { výjimek }\end{array}$ & \begin{tabular}{|r|} 
Skutečný \\
počet výjimek \\
v celém \\
období \\
\end{tabular} & $\begin{array}{r}\text { Skutečný } \\
\text { počet } \\
\text { výjimek } \\
\mathrm{v} 1 . \text { třetině } \\
\end{array}$ & $\begin{array}{r}\text { Skutečný } \\
\text { počet } \\
\text { výjimek } \\
\text { ve 2. třetině }\end{array}$ & $\begin{array}{r}\text { Skutečný } \\
\text { počet } \\
\text { výjimek } \\
\text { ve 3. tř̌etině } \\
\end{array}$ \\
\hline \multirow[t]{4}{*}{ DJI, USD } & $85,00 \%$ & $441 / 147$ & 424 & 150 & 130 & 145 \\
\hline & $95,00 \%$ & $147 / 49$ & 156 & 44 & 40 & 72 \\
\hline & $99,00 \%$ & $29 / 10$ & 39 & 12 & 7 & 20 \\
\hline & $99,50 \%$ & $15 / 5$ & 24 & 8 & 4 & 12 \\
\hline \multirow[t]{4}{*}{ FTSE, GBP } & $85,00 \%$ & $441 / 147$ & 425 & 148 & 109 & 169 \\
\hline & $95,00 \%$ & $147 / 49$ & 160 & 58 & 36 & 66 \\
\hline & $99,00 \%$ & $29 / 10$ & 40 & 14 & 5 & 21 \\
\hline & $99,50 \%$ & $15 / 5$ & 18 & 4 & 1 & 13 \\
\hline \multirow[t]{4}{*}{ N225, JPY } & $85,00 \%$ & $441 / 147$ & 420 & 147 & 128 & 145 \\
\hline & $95,00 \%$ & 147 / 49 & 144 & 46 & 46 & 52 \\
\hline & $99,00 \%$ & $29 / 10$ & 31 & 9 & 12 & 10 \\
\hline & $99,50 \%$ & $15 / 5$ & 17 & 4 & 5 & 8 \\
\hline \multirow[t]{4}{*}{ SMI, CHF } & $85,00 \%$ & $441 / 147$ & 434 & 147 & 132 & 156 \\
\hline & $95,00 \%$ & $147 / 49$ & 149 & 47 & 40 & 63 \\
\hline & $99,00 \%$ & $29 / 10$ & 36 & 10 & 7 & 19 \\
\hline & $99,50 \%$ & $15 / 5$ & 17 & 6 & 0 & 11 \\
\hline \multirow{4}{*}{$\begin{array}{l}\text { Tangenciálnî } \\
\text { portfolio }\end{array}$} & $85,00 \%$ & $441 / 147$ & 427 & 147 & 125 & 156 \\
\hline & $95,00 \%$ & $147 / 49$ & 159 & 47 & 42 & 71 \\
\hline & $99,00 \%$ & $29 / 10$ & 36 & 8 & 9 & 19 \\
\hline & $99,50 \%$ & $15 / 5$ & 15 & 6 & 2 & 7 \\
\hline \multirow{4}{*}{$\begin{array}{l}\text { Rovnoměrně } \\
\text { citlivé portfolio }\end{array}$} & $85,00 \%$ & $441 / 147$ & 405 & 136 & 122 & 148 \\
\hline & $95,00 \%$ & $147 / 49$ & 150 & 46 & 37 & 67 \\
\hline & $99,00 \%$ & $29 / 10$ & 29 & 7 & 3 & 19 \\
\hline & $99,50 \%$ & $15 / 5$ & 19 & 3 & 1 & 15 \\
\hline \multirow{4}{*}{$\begin{array}{l}\text { Portfolio } \\
\text { s minimálním } \\
\text { rozptylem }\end{array}$} & $85,00 \%$ & $441 / 147$ & 413 & 145 & 115 & 154 \\
\hline & $95,00 \%$ & $147 / 49$ & 152 & 43 & 39 & 70 \\
\hline & $99,00 \%$ & $29 / 10$ & 30 & 8 & 4 & 18 \\
\hline & $99,50 \%$ & $15 / 5$ & 17 & 4 & 1 & 12 \\
\hline
\end{tabular}


Rovněž ve třetí třetině uvažovaného období je skutečný počet výjimek statisticky rozdílný od počtu předpokládaného. $\mathrm{V}$ této třetině je však pozorovaný počet výjimek vyšší, model tedy riziko podhodnocuje. Toto je opět zapř́ičiněno změnou volatility, která se během roku několikanásobně zvýšila. Na toto zvýšení volatility výnosů jednotlivých aktiv nebyl model vzhledem k relativně dlouhému období použitému pro odhad parametrů schopen pružně reagovat a dochází tedy k vysokému výskytu výjimek.

Z výsledků lze tedy shrnout, že pokud je volatilita výnosů konstantní (první třetina uvažovaného období), je použitý model vhodný pro odhad hodnoty VaR. Dochází-li však ke změnám volatility, odhad hodnoty VaR je zkreslený a dochází k jeho nadhodnocení (druhá třetina uvažovaného období) nebo podhodnocení (tř̌etí třetina uvažovaného období). Rovněž důležitým zjištěním je, že i když je model určen jako vhodný na základě delšího časového období (v tomto případě celého uvažovaného období), nemusí být ke stejnému závěru dospěno i v rámci jednotlivých kratších subobdobí (viz druhá a třetí třetina uvažovaného období).

Souvislost mezi počtem pozorovaných výjimek (tedy i přesností modelování) a vývojem volatility v jednotlivých třetinách uvažovaného období platí pro všechna uvažovaná portfolia pouze $\mathrm{v}$ průměru. Počty pozorovaných výjimek se u jednotlivých portfolií liší. Nejlepších výsledků dosahoval model pro modelování investice do japonského akciového indexu Nikkei 225, pro který bylo možno pozorované počty výjimek akceptovat pro všechny třetiny uvažovaného období a rovněž pro všechny uvažované hladiny spolehlivosti $\alpha$. Rovněž pro investici do amerického akciového indexu Down Jones Industrial Average bylo možno pozorované počty výjimek akceptovat pro první i druhou třetinu uvažovaného období. Naproti tomu pro investice do britského a švýcarského akciového indexu byly počty výjimek akceptovatelné pouze pro první třetinu uvažovaného období. Z uvedeného srovnání lze tedy usuzovat, že mezi průběhem výnosů jednotlivých akciových indexů (nebo jejich korelace $\mathrm{s}$ výnosy př́slušného měnového kurzu) jsou rozdíly. Vzhledem k tomu, že uvažovaný model nedosahoval dostatečných výsledků $v$ druhé a třetí třetině uvažovaného období pro modelování výnosů některých akciových indexů, není překvapivé, že i složená portfolia, která tyto indexy obsahovala, nebyla modelována dostatečně kvalitně. Nejlepších výsledků bylo dosaženo pro tangenciální portfolio (složené pouze $\mathrm{z}$ investic do amerického a švýcarského akciového indexu). Naproti tomu více diverzifikovaná portfolia (rovnoměrně citlivé portfolio a portfolio s minimálním rozptylem) dosahovala horších výsledků. Lze tedy vidět, že chyby v modelování jednotlivých rizikových faktorů se nevykompenzují, ale spíše zprůměrují, což souvisí s kladnou korelací mezi výnosy jednotlivých akciových indexů (resp. měnových kurzů).

\section{Závěr}

Modelování rizika je bezesporu jedním z hlavních úkolů risk managementu. V tomto článku byla ověřena prresnost odhadu hodnoty $\mathrm{VaR}$ pro různá portfolia a hladiny spolehlivosti v závislosti na různých charakteristikách trhu. Byl uvažován trh s konstantní volatilitou, s klesající volatilitou a se skokovým nárůstem volatility. Hodnota VaR byla v článku odhadována pomocí simulace Monte Carlo a Normálního inverzního Gaussova modelu sdruženého Studentovou kopula funkcí.

Z prezentovaných výsledků vyplývá, že pokud je sledované období charakteristické konstantní volatilitou výnosů, je odhad rizika na bázi metodologie VaR pomocí uvažovaného modelu přesný. Pokud ve sledovaném období dochází ke změnám volatility výnosů, nelze již 
model pro odhad hodnoty VaR použít. Bylo zjištěno, že při klesající volatilitě výnosů použitý model riziko nadhodnocuje. Naopak při skokovém nárůstu volatility výnosů model riziko podhodnocuje. Toto je zapř́čciněno způsobem odhadu parametrů, které jsou odhadovány pomocí metody momentů z historických charakteristik časových řad. Pro modelování rozptylu by bylo vhodnější použít některý model typu ARCH nebo GARCH. Pro praktické využití tedy navrhovaný model bez použití modelu podmíněného rozptylu výnosů není vhodný, nebot' období s konstantní volatilitou výnosů nejsou na finančních trzích typická. Další výzkum lze tedy spatřovat právě v začlenění modelu GARCH.

Výsledky článku rovněž ukazují, že i přestože je model statisticky akceptovatelný pro dlouhé časové období, neznamená to, že je model vhodný pro odhad rizika. Pro část časové řady může model riziko systematicky nadhodnocovat a $v$ další části zase systematicky podhodnocovat, přičemž tyto odchylky se v dlouhé časové řadě navzájem vykompenzují. Použití dostatečně dlouhé časové řady pro zpětné testování tedy není zárukou správného závěru o vhodnosti modelu.

\section{Literatura:}

[1] ALEXANDER, C. 2008. Value-at-Risk Models. Chichester: Wiley, 2008. ISBN 978-0470-99788-8.

[2] ALEXANDER, C.; SHEEDY, E. 2008. Developing a stress testing framework based on market risk models. Journal of Banking and Finance, 2008, roč. 32, č. 10, s. 2220-2236. ISSN 03784266.

[3] ARTZNER, P., aj. 1999. Coherent measures of risk. Mathematical Finance, 1999, roč. 9, č. 3, s. 203-228.

[4] BARNDORFF-NIELSEN, O. E. 1995. Normal inverse Gaussian distributions and the modeling of stock returns. Aarhus, 1995. Disertační práce. Aarhus University.

[5] BARONE-ADESI, G.; GIANNOPOULOS, K.; VOSPER, L. 1999. VaR without Correlations for N Linear Portfolios. Journal of Futures Markets, 1999, roč. 19, s. 853602.

[6] CONT, R., TANKOV, P. 2003. Financial Modelling with Jump Processes. Chapman \& Hall, 2003. ISBN 1-58488-413-4.

[7] DEMARTA, S.; MCNEIL, A. J. 2005. The t copula and related copulas. International Statistical Review, 2005, roč. 73, č. 1, s. 111-129. ISSN 03067734.

[8] HANSEN, B. E. 1994. Autoregressive conditional density estimation. International Economic Review, 1994, roč. 35, č. 3, s. 705-730.

[9] HULL, J. 2007. Risk Management and Financial Institutions. Upper Saddle River: Prentice Hall, 2007. ISBN 0-13-239790-0.

[10] CHERUBINI, G.; LUCIANO, E.; VECCHIATO, W. 2004. Copula Methods in Finance. Chichester: Wiley, 2004. ISBN 0-470-86344-7.

[11]KRESTA, A. 2010. Portfolio Value at Risk estimation utilizing Lévy models coupled together by copula functions. In Tichý, T., aj. Proceedings of 47th EWGFM meeting. Prague: X-MEDIA servis, 2010. s. 89-100. ISBN 978-80-248-2351-5.

[12]KRESTA, A. 2011. Testování vybraných modelů odhadu hodnoty VaR. Ekonomická revue - Central European Review of Economic Issues, 2011, roč. 14, č. 3, s. 199-210.

[13] KUPIEC, P. 1995. Techniques for verifying the accuracy of risk measurement models. Journal of Derivatives, 1995, roč. 3, č. 2, s. 73-84.

[14] NELSEN, R. B. 2006. An Introduction to Copulas. Springer, 2006. ISBN 978-038728659-4. 
[15]PRAUSE, K. 1999. The Generalized Hyperbolic Model: Estimation, Financial Derivatives, and Risk Measures. Freiburg, 160 s., 1999. Disertační práce. AlbertLudwigs-Universität Freiburg.

[16] RANK, J. 2006. Copulas: From Theory to Application in Finance. London: Risk Books, 2006. ISBN 978-1-904339-45-8.

[17] SKLAR, A. 1959. Fonctions de repartition à $\mathrm{n}$ dimensions et leurs marges. Publ. Inst. Statist. Univ. Paris, 1959, roč. 8, s. 229-231.

[18] TICHÝ, T. 2010. Posouzení odhadu měnového rizika portfolia pomocí Lévyho modelů. Politická ekonomie, 2010, roč. 58, č. 4, s. 504-521.

[19]ZMEŠKAL, Z, aj. 2004. Finanční modely. 2. vyd. Praha: Ekopress, 2004. ISBN 8086119-87-4.

\section{JEL G15, G17}

Ing. Aleš Kresta, Ph.D.

Katedra financí

Ekonomická fakulta

VŠB-TU Ostrava

Sokolská tř. 33, 70121 Ostrava

ales.kresta@seznam.cz 